\title{
Application of magnetotelluric geophysical technique in delineation of zones of high groundwater potential for borehole drilling in five communities in the Agona East District, Ghana
}

\author{
Victor Ofori Agyemang ${ }^{1}$ (D)
}

Received: 3 January 2020 / Accepted: 28 April 2020 / Published online: 11 May 2020

(c) The Author(s) 2020

\begin{abstract}
Hydrogeological investigations to delineate zones of high groundwater potential in five selected communities in the Agona East District of Ghana have been successfully carried out using the magnetotelluric geophysical technique. The technique has successfully been applied to delineate potential zones of high groundwater potential in terms of location and depth-to-aquifer zones. The study has revealed that the apparent electrical resistivity of the subsurface of the study area to a depth of $300 \mathrm{~m}$ displays the stratigraphic layers of different resistivities. Eburnean Plutonic suite and the Tamnean Plutonic Suite were the two major geologic materials encountered in the study area. The Eburnean Plutonic suite shows relatively low resistivity rang of 0-480 $\Omega \mathrm{m}$ at a depth of 0-300 $\mathrm{m}$ which indicates the presence of weathered zones capable of holding water. However, the Tamnean Plutonic Suites shows a resistivity range of 200-2800 $\Omega \mathrm{m}$ which shows that it is a consolidated rock with no developed primary and/or secondary hydrogeological properties such as porosity and permeability. Therefore, the exploration of groundwater in the Tamnean Plutonic Suite depends strictly on the fracture zones which may contain water. Again, the study revealed that the prevailing aquifer systems of the study area are not regional but are controlled by fractures and weathered zones. Therefore, it is highly envisaged that groundwater would be intersected at the saprock region which is the fractured and weathered zone between fresh bedrock and the regolith at the depth of 80-100 $\mathrm{m}$. Also, the study has shown the capability of the magnetotelluric geophysical technique to delineate zones of high groundwater potentials for borehole drilling purpose.
\end{abstract}

Keywords Agona east district · Groundwater · Magnetotelluric technique

\section{Introduction}

Nowadays, the increase in population growth rate in all parts of the world has increased the growing need to explore and characterized groundwater by using improved geophysical techniques. Techniques that characterize the electrical resistivity of the ground relate to pore fluid salinity and effective porosity and therefore improve them help a lot in the groundwater exploration (Archie 1942). The current study employs the MT technique which has been used by researchers in different parts of the world (Kaufman and Keller 1981; Tinlin et al. 1988; Dobrin and Savit 1988; Brasse 1989; Bernard

Victor Ofori Agyemang

oforiagyemangvictor@yahoo.com

1 Hydrogeological Unit, Community Water and Sanitation Agency, P. O. Box 1315, Cape Coast, Ghana et al. 1990; Bartel 1991; Vozoff 1991; Bourgeois et al. 1994; Nichols et al. 1994; Chave and Jones 2012).

One of the major uses of groundwater resources in Ghana is for drinking purpose. This is because unlike the urban cities in Ghana where the Ghana Water Company Limited supply portable water for drinking and other domestic purposes, the rural communities depend on boreholes fitted with handpump and limited mechanized systems as improved sources of water supply. Agona East District is not exempted from this water supply dilemma in the country; therefore, both the government and non-governmental organizations (NGOs) in the water, sanitation and hygiene (WASH) sector have invested hugely in the improved sources of water supply in the district. This is to ensure that the provision of sustainable water supply to the communities would go a long way to improve the living standards of the rural folks. As part of the strategic plan to guarantee a sustainable supply of water to the beneficiary communities, donors add hydrogeophysical 
surveys to conduct detailed geophysical studies to explore the possibility of harnessing deep-seated aquifers systems. It is against this background that Community Water and Sanitation Agency, Cape Coast, was commissioned to conduct hydrogeophysical studies to delineate most promising zones where about five sustainable boreholes could be drilled to augment the existing ones. Hence, the objective of the hydrogeological investigation is to identify zones of high groundwater potential for drilling of sustainable boreholes.

\section{The study area}

The Agona East District lies within a wet semi-climatic regime, which is characterized by two wet seasons of unequal intensity of rainfall (Dickson and Benneh 2004). Annual rainfall intensity ranges between 1200 and $1500 \mathrm{~mm}$ with the mean annual temperature of about $27^{\circ} \mathrm{C}$. The first rainfall season begins from May to June with the peak occurring within July. The second rainy period is from September to October. The vegetation cover is of the moist-semi deciduous forest type. Here, the trees exhibit deciduous habit. Thus, most of the trees do not shed all their leaves during the long dry periods of the year (November-March) when the influence of Harmattan is very relatively pronounced. Annual evapotranspiration conditions ranged between 1450 and $1500 \mathrm{~mm}$.

The study area is primarily underlain by Ebunean plutonic suite. This formation is associated with Granitoid gneiss, biotite gneiss (GSD 2009). The area lies within a geologic contact Tamnean Plutonic Suite as shown in Fig. 1. The proximity of the area to geologic contacts, fractures could be enhanced to facilitate groundwater accumulation. Also, there are a lot of fractures prevailing within the area. This could be attributed to geologic tectonic activities (Kesse 1985). Generally, the granites and granitoids are associated with secondary porosity as a result of jointing, fracturing and weathering. Fault zones are generally favorable location for groundwater storage. Aquifers are therefore located where secondary porosity has developed. The two main aquifer types are the weathered zone or 'regolith', which develops on the crystalline basement rocks, and fracture zones within the bedrock. Boreholes tapping from the granitic aquifers within the study area are low yielding and have an average borehole yield of about $0.41 \mathrm{~m}^{3} / \mathrm{h}$ (Dapaah-Siakwan and

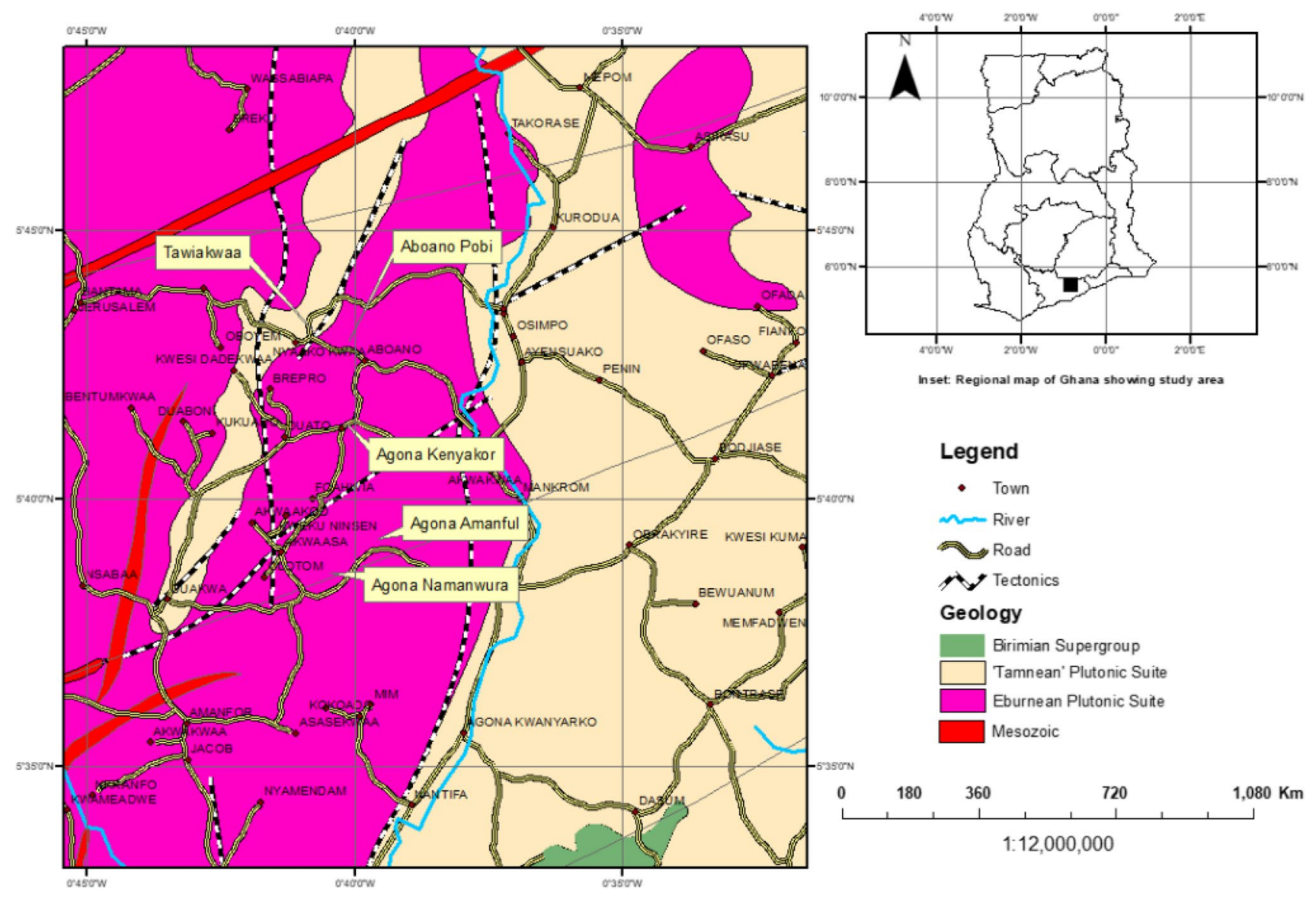

Fig. 1 Geological map of the study area (modified after GSD, 2009) 
Gyau-Boakye 2000). The success rate of drilling productive borehole is about $68 \%$. Where the saturated regolith is thin or absent, sufficient permeability has to be identified in the fractured bedrock to obtain any appreciable groundwater yields. Borehole yields in fractured rock aquifers increase with fracture intensity and degree of interconnections. With improved hydrogeological and geophysical studies high yielding boreholes are expected to be drilled to guarantee sustainable water supply for domestic and industrial usage. (Figs. 2, 3)
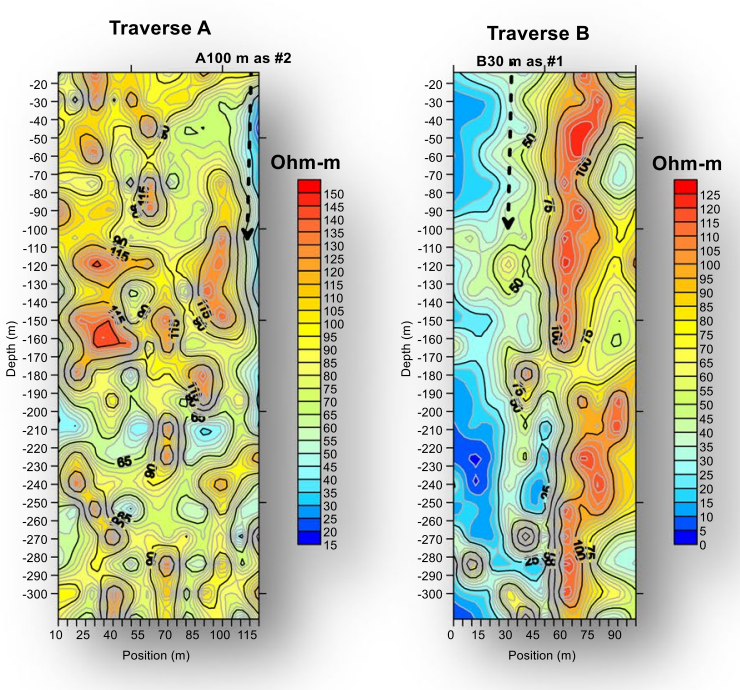

(a) Kenyakor

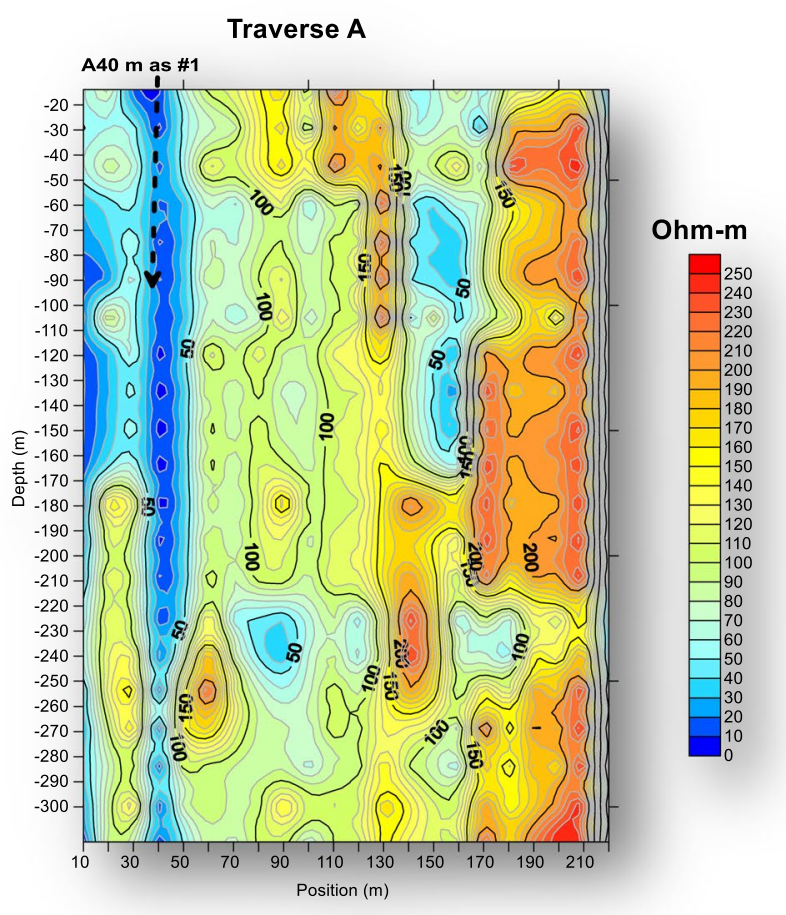

(c) Agona Amanful

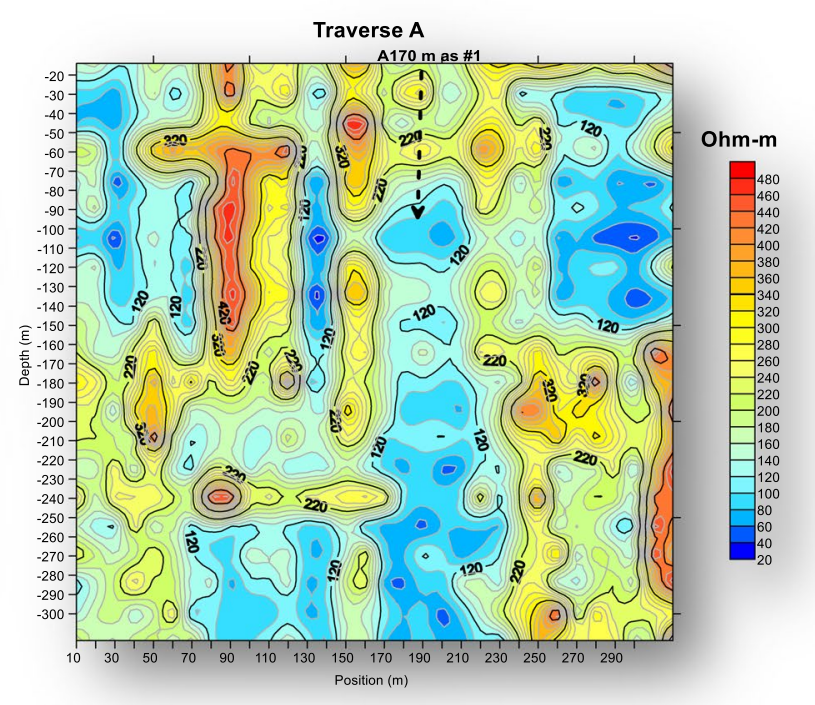

(b) Aboano Pobi

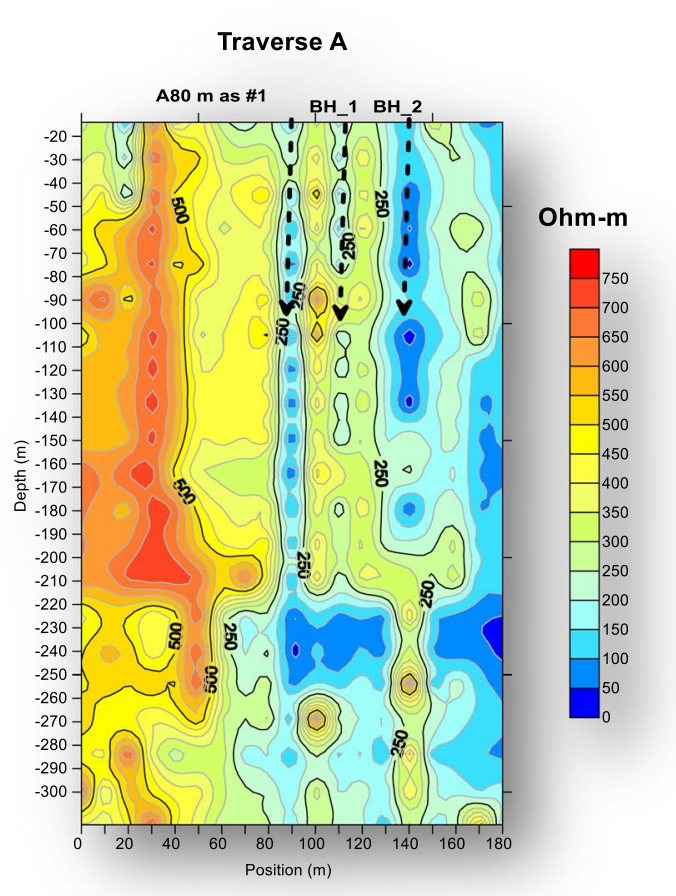

(d) Agona Namanwura.

Fig. 2 (a-d) Two-dimensional-apparent geo-electrical resistivity pseudo-section of the surface at four communities of the study area underlain by the Eburnean Plutonic Suite 


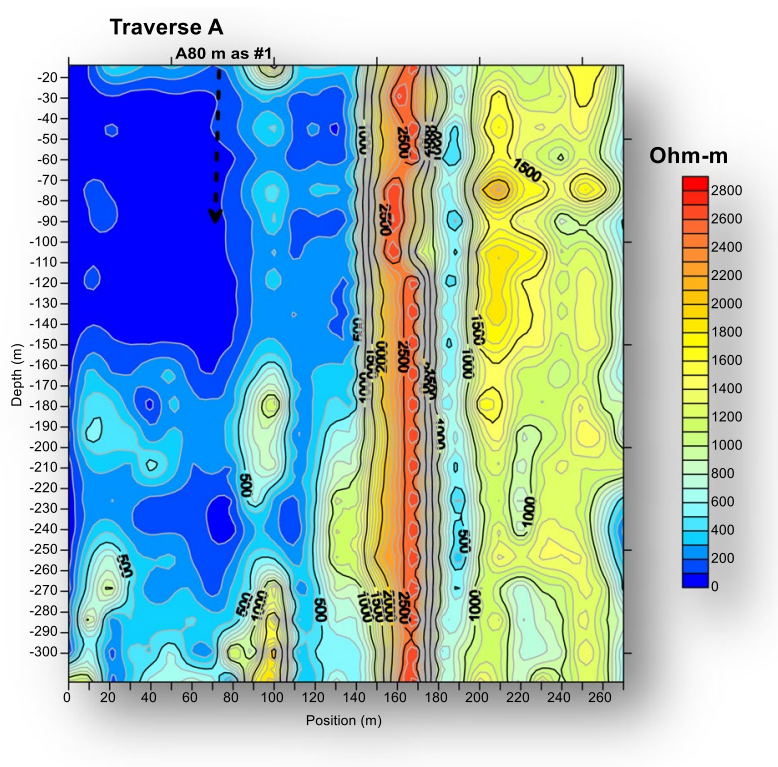

Fig. 3 Two-dimensional-apparent geo-electrical resistivity pseudosection of the surface at Tawiakwaa underlain by the Tamnean Plutonic Suite

\section{Methodology}

The geophysical technique employed in this study was the magnetotellurics (MT) method. According to Vozoff (1991), the magnetotelluric method is a passive-surface geophysical technique that uses the Earth's natural electromagnetic fields to investigate the electrical resistivity structure of the subsurface from depths of tens of meters to tens of kilometers. Natural variations of the Earth's magnetic and electric fields were measured and recorded at each magnetotelluric station. The magnetotelluric method is well-suited for studying complicated geological environments because the electric and magnetic relations are sensitive to vertical and horizontal variations in resistivity. High-resolution shallow subsurface characterization is possible for closely spaced stations, but the resolution of the subsurface decreases for deeper measurements and for widely spaced stations. The method is capable of establishing whether the electromagnetic fields are responding to subsurface rock bodies of effectively one, two or three dimensions. Investigation depth ranges from $300 \mathrm{~m}$ below ground by recording higher frequencies down to $10,000 \mathrm{~m}$ or deeper with long-period soundings.

The MT geophysical technique involves the measurement of the earth's electrical conductivity and magnetic field over a range of frequency (Vozoff 1972). This technique makes use of an EM penetrating energy that moves through the earth. The depth of penetration is dependent on the resistivity of the geologic materials in which it penetrates and the frequency. The ratio $\mathrm{E} / \mathrm{H}$ gives the complex impedance $\mathrm{Z}$.
The orthogonal and parallel components of $\mathrm{E}$ and $\mathrm{H}$ generate the impedance tensor $\mathrm{Z}$. The vertical magnetic field $\mathrm{H}$ relates to the horizontal components by the magnetic transfer functions (Vozoff 1972). Sounding curves are drawn as a function of frequency. In this curves, $Z_{i j}$ is denoted the apparent resistivity and the phase. The measurement of the vertical variation of conductivity gives one-dimensional (1D) earth model. In such case, the diagonal components of $\mathrm{Z}$ are zero and $\mathrm{Z}_{\mathrm{xy}}=-\mathrm{Z}_{\mathrm{yx}}$. The measurement of the variation of conductivity in two different directions gives two-dimensional (2D) earth model. The tensor can be positioned such that the off-diagonal components reach a minimum value a maximum value for each strike. In this case, the diagonal components remain zero but the vertical magnetic field is no longer equal to zero. The measurement of the variation of conductivity in three different directions within the earth gives three-dimensional (3D) earth model. Here, all the Z components are nonzero. In situations whereby, skin depth is greater than the 3D conductive body, the flow of electric current occurs at a specific scale and the measured $\mathrm{Z}$ is influenced by galvanic distortion (Park 1985). In this case, the flow of electric current is independent of the frequency and will be reflected at lower frequencies. Vozoff (1972), Kaufman and Keller (1981), as well as Berdichevsky and Zhdanov (1984), give good explanations on the MT theory. Vertical resistivity variation with depth was measured at 7-15 MT soundings stations along six different 300-m long profiles. A V-5 system 2000 of Phoenix Geophysics was used to do the measurement by following the procedures suggested by Gamble et al. (1979). In this study, data of field coherencies greater than 0.7 and apparent resistivity that showed errors less than $10 \%$ were used.

\section{Results and discussion}

The study area is underlain by the Eburnean and Tamnean Plutonic Suites. Four communities, namely Kenyakor, Aboano Pobi, Agona Amanful and Agona Namanwura are underlain by the Eburnean Plutonic suite (2116-2072 Ma), while Tawiakwaa is underlain by the Tamnean Plutonic Suite (2134-2118 Ma). According to GSD (2009), the two intrusive rocks together with the Mesozoic intrusive which consists mainly of mafic dikes are the major intrusive rocks in Ghana.

The Eburnean Plutonic Suite with undifferentiated biotite-granitoid as the main rock type weather to form clay and sandy-clay overburden, while the bedrock is marked with multiple fracture sections (GSD 2009). It is made of rocks such as biotite granite, hornblende-biotite tonalite, gabbro, ultramafic and minor mafic igneous rock undifferentiated (GSD 2009). This intrusion is mostly found in the Birimian basin sediments; however, it is also locally located in some 
Birimian volcano-plutonic belts. This intrusive type also includes minor K-rich granitoid in some parts of Ghana such as Bongo Granite in the Upper East Region (GSD 2009). In this study, the probable aquifer zone of the Eburnean Plutonic suite was identified at a depth of $80-100 \mathrm{~m}$. The range of electrical resistivity values recorded is $0-750 \Omega \mathrm{m}$. The relatively low resistivity in the Eburnean Plutonic suite indicates the weathered zones which are capable of holding water. The low resistive sedimentary cover rocks appear to be thin in thickness. Between the cover sedimentary layer and the crystalline basement rock is the weathered zone of different degree of fracturing at different depths. This zone shows anomalous reading lower than the sedimentary cover and the crystalline basement rocks. This freshwatersaturated zone of the geological unit is not regional and the hydrogeological conditions are controlled by weathering and fractures. This means borehole drilled through this aquifer may not be able to have a high yield. This agrees with a study conducted by Dapaah-Siakwan and Gyau-Boakye (2000). In their study, they assessed the existing boreholes within the Eburnean Plutonic Suite around the study area and noticed that the success rate of drilling wet well is about $68 \%$ with a yield of $1-9 \mathrm{~m}^{3} / \mathrm{h}$.

The second geological unit that underlain the study area is the Tamnean Plutonic Suite. Previous investigations including the analysis of vertical electrical sounding data and borehole drilling logs revealed a crystalline rock with limited fractures at some points. It consists of rocks such as Hornblende-biotite-granitoid (tonalite, granodiorite and alkali granite, syenite), and it is found in parts of Eastern, Upper East, Upper West, Northern and Central Regions of Ghana (GSD 2009). It is poorly permeable rocks with fracture porosity and high resistivity values of 200-2800 $\Omega \mathrm{m}$ to a depth of $300 \mathrm{~m}$. The high bedrock resistivities $(>700 \Omega \mathrm{m})$ which continuously increase with depth indicate a massive crystalline granitic rock with little or no fracture to enhance groundwater development. Different studies have suggested that the granites which underlain the study area are massive and less fractured with minimal water storage potentials. Okrah et al. (2012) assert that bedrock resistivity greater than $800 \Omega \mathrm{m}$ in the granitic environment may lead to dry wells. This assertion is because the granitic environment of high resistivity values $(>800 \Omega \mathrm{m})$ is considered to have crystalline underlying rocks with least or no secondary porosity. This suggestion agrees with the previous investigations which include the analysis of vertical electrical sounding data, borehole drilling logs as well as verbal information obtained from the residence of Tawiakwaa which indicates that all drilling attempts to a depth of $100 \mathrm{~m}$ in the community failed without any volume of water except at two locations at the extreme ends of the community where two successful boreholes fitted with hand pumps are located. These two locations are identified on the geological map of Ghana with major faults (Fig. 1) which serve as reservoirs for the groundwater. The failure of the borehole drilling attempt was because the community is underlain by very massive crystalline granitic rocks that have insignificant fractures to enhance groundwater development. This observation also agrees with the observation of Manu et al. (2019) who studied the groundwater potentials of the Granitoid Undifferentiated and the Sekondian Group and had three unsuccessful boreholes in Granitoid but ten successful boreholes in the Sekondian Group in Cape Coast Municipality in the Central Region of Ghana.

\section{Conclusion}

The magnetotelluric geophysical technique has successfully been applied to delineate potential zones of high groundwater potential in terms of location and depth-toaquifer zones. The study shows the apparent electrical resistivity of the subsurface of the study area to a depth of $300 \mathrm{~m}$ displaying the stratigraphic layers of different resistivities. The Eburnean Plutonic suite and the Tamnean Plutonic Suite are the two major geologic materials encountered in the study area. The Eburnean Plutonic suite shows relatively low resistivity range of $0-480 \Omega \mathrm{m}$ at a depth of 0-300 $\mathrm{m}$ which indicates the presence of weathered zones capable of holding water. However, the Tamnean Plutonic Suites show a resistivity range of 200-2800 $\Omega \mathrm{m}$ which shows that it is a consolidated rock with no developed primary and/or secondary hydrogeological properties such as porosity and permeability. Therefore, the exploration of groundwater in the Tamnean Plutonic Suite depends strictly on the fracture zones of the bedrock which may contain water. It also revealed that the prevailing aquifer systems of the study area are not regional but are controlled by fractures and weathered zones. Therefore, it is highly envisaged that groundwater would be intersected at the saprock region which is the fractured and weathered zone between fresh bedrock and the regolith at the depth of $80-100 \mathrm{~m}$. The study has shown the capability of the magnetotelluric geophysical technique to delineate zones of high groundwater potentials for drilling purpose.

Acknowledgements The author is grateful to the Management of the Community Water and Sanitation Agency, Cape Coast for their support during data collection.

\section{Compliance with ethical standards}

Conflict of interest The author declares that he has no conflict of interest. 
Open Access This article is licensed under a Creative Commons Attribution 4.0 International License, which permits use, sharing, adaptation, distribution and reproduction in any medium or format, as long as you give appropriate credit to the original author(s) and the source, provide a link to the Creative Commons licence, and indicate if changes were made. The images or other third party material in this article are included in the article's Creative Commons licence, unless indicated otherwise in a credit line to the material. If material is not included in the article's Creative Commons licence and your intended use is not permitted by statutory regulation or exceeds the permitted use, you will need to obtain permission directly from the copyright holder. To view a copy of this licence, visit http://creativecommons.org/licenses/by/4.0/.

\section{References}

Archie CE (1942) The electrical resistivity log as an aid in determining some reservoir characteristics. J Petrol Technol, 5

Bartel LC (1991) Results from a controlled-source audio frequency magnetotelluric survey to characterize an aquifer. In: Ward SH (ed), Geotechnical and environmental geophysics. vol 5 of investigations in geophysics, SEG, pp 219-233

Berdichevsky MN, Zhdanov MS (1984) Advanced Theory of Deep Geomagnetic Sounding. Elsevier, Amsterdam, p 408

Bernard J, Vachette C, Valle P, (1990) Deep groundwater survey with audiomagnetotelluric soundings. In: SEC, 60th Annu. Int. Meeting, vol 60, pp 528-531

Bourgeois B, Mathieu F, Vachette C, Vaubourg P (1994) AMT measurements compared with gravimetry and magnetometry for structural study of a sedimentary basin: Letlhakeng-Botlhapatlou groundwater project. Botswana J Appl Geophys 31:7-25

Brasse H (1989) Audiomagnetotelluric investigations of hydrogeological and tectonic problems in the eastern Sahara. In: Gadsden M (ed), Proc. of the 6th scientific assembly of the int. assoc. of geornagnctism and aeronomy, vol 53 of IAGA Bulletin, p 165

Chave A, Jones A (2012) The magnetotelluric method, theory and practice. Cambridge University Press, Cambridge

Dapaah-Siakwan S, Gyau-Boakye P (2000) Hydrogeological framework and borehole yields in Ghana. Hydrogeol J, 400-416

Dickson B, Benneh G (2004) A new geography of Ghana. Longman Group Ltd, London, UK
Dobrin MD, Savit CH (1988) Introduction to geophysical prospecting, 4th edn. McGraw-Hill, New York, p 867

Gamble TD, Goubau WM, Clarke J (1979) Magnetotellurics with a remote magnetic reference. Geophysics 44:53-68

Geological Survey Department G (2009) Geological map of Ghana 1: 000 000. Geological map of Ghana. Geological survey department, GSD

Kaufman AA, Keller GV (1981) The magnetotelluric sounding method, methods in geochemistry and geophysics, vol 15. Elsevier, New York, $\mathrm{p} 595$

Kesse GO (1985) The mineral and rock resources of Ghana. Balkema, Rotterdam, p 610

Manu E, Agyekum WA, Duah AA, Tagoe R, Preko K (2019) Application of vertical electrical sounding for groundwater exploration of Cape coast municipality in the central region of Ghana. Arabian J Geosci 12:196

Nichols EA, Morrison HF, Lee S, (1994) Controlled source magnetotellurics for groundwater. In: SEG, 64th Annu. int. meeting, pp 553-554

Okrah C, Danuor SK, Dapaah-Siakwan S (2012) Groundwater exploration in granitic rock formation of Komenda/Edina/Eguafo/Abirem district using integrated geophysical techniques. J Ghana Sci Assoc 14(2):56-72

Park SK (1985) Distortion of magnetotelluric sounding curves by three-dimensional structures. Geophysics 50:785-797

Tinlin RM, Hughes LJ, Anzzolin AR (1988) The use of controlled source audio magnetotellurics (CSAhlT) to delineate zones of groundwater contamination: a case history. In: Collins AG, Johnson AI (eds). Groundwater contamination field methods. vol 963 of ASTM Spec. Tech. Publ. American society for testing and materials, pp I O I-I IS

Vozoff K (1972) The magnetotelluric method in the exploration of sedimentary basins. Geophysics 37:98-141

Vozoff K (1991) The magnetotelluric method. In: Nabighian MN (ed) Electromagnetic methods in applied geophysics, part B, vol 2. Society of exploration geophysicists. Tulsa, Okla, pp 641-711

Publisher's Note Springer Nature remains neutral with regard to jurisdictional claims in published maps and institutional affiliations. 